\title{
Concentration effect of polyethylene glycol in evaluation of grain legumes for drought tolerance
}

\author{
Nadiia Vus ${ }^{1}$, \\ Antonina Vasylenko', \\ Vyacheslav Lutenko ${ }^{1}$, \\ Lyubov Kobyzeva ${ }^{1}$, \\ Olha Bezuhla ${ }^{1}$, \\ Larisa Shevchenko ${ }^{1}$, \\ Sergey Ponurenko ${ }^{1}$, \\ Feng Baili², Dmitry Saliy ${ }^{1}$ \\ ${ }^{1}$ Plant Production Institute \\ named after VYa Yuriev of NAAS, \\ 142 Moskovskyi Avenue, \\ 61060 Kharkiv, Ukraine \\ ${ }^{2}$ State Key Laboratory \\ of Crop Stress Biology in Arid Areas, \\ College of Agronomy, \\ Northwest A \& F University, \\ 712100 Yangling, \\ Shaanxi Province, China \\ Email:vus.nadezhda@gmail.com
}

The article covers selection of differentiating concentrations of PEG-6000 for assessing genetic resource collections of pea, chickpea and lentil.

The germinability of 4 accessions of each crop in 5, 10, 15, 20 and 25\% PEG-6000 solutions was evaluated. The results showed that 25\% PEG-6000 completely inhibited growth processes in all the crops; 5 and 10\% PEG-6000 did not affect the germinability of lentil seeds; and the maximum differentiation was observed at an osmotic concentration of 20\%. In chickpea, there were no seedlings even in 20\% PEG-6000. In 15\% PEG-6000, seeds of drought-tolerant accessions UD0500022 and Dniprovskyi Vysokoroslyi only sprouted; and 5 and 10\% solutions had the maximum differentiating effect. Pea germination in PEG-6000 solutions of different concentrations demonstrated that only one accession could germinate in 20 and $15 \%$ solutions. Two accessions gave seedlings in $10 \%$ PEG-6000, and 5\% solution had almost no effect on the germinability of pea seeds.

Keywords: Cicer arietinum L., germinability, Lens culinaris Medik, method, Pisum sativum L., cultivars, seeds

\section{INTRODUCTION}

When it comes to global climate changes, an increase in the length of dry periods is predicted, which will most significantly affect agriculture. This problem is especially acute for countries whose populations depend entirely on agricultural productivity (Semba, 2016). However, even for economically developed regions, cheaper food will always be relevant. Legume cultivation on bogharic lands considerably reduces the cost of their production, but in this case, yields largely depend on weather conditions (Zander et al., 2016). Early-sown legumes, such as pea, chickpea and lentil, can be sown in early spring, which allows them to avoid drought and give a yield before unfavourable summer conditions occur (Yadav et al., 2006). However, they greatly depend 
on water supply in the seedling phase. To imbibe water, seeds of these crops, especially chickpea and garden pea having large surface areas of seeds due to wrinkled seed coats, require large amounts of soil water (Sichkar et al., 2018).

Legumes as a source of high-quality protein are a basis of food safety of the population (Grain Legumes..., 2016). The FAO data show that in 2017 the pea-sown area in the world amounted to 8.14 million ha, with the gross output of $16.21 \mathrm{mil}-$ lion tons and the average yield of $1.99 \mathrm{t} / \mathrm{ha}$ (FAOSTAT). In Ukraine, the pea-sown area amounted to 252.8 thousand ha in 2019 , with the gross output of 585.82 thousand tons and the yield of 2.32 t/ha (Production Volume..., 2019). Almost $80 \%$ of the global chickpea production is concentrated in South and Southeast Asia. The gross output of chickpea in Ukraine is 14.78 million tons from 14.56 million hectares; with the average yield of $1.01 \mathrm{t} / \mathrm{ha}$. The total production of lentil in the world is 7.59 million tons, with the area of $6.58 \mathrm{million} / \mathrm{ha}$ and the average yield of $1.15 \mathrm{t} / \mathrm{ha}$ (FAOSTAT). In Ukraine in 2019, chickpea production amounted to 41.21 thsd. tons from 30.4 thsd. ha; lentil production 8.04 thsd. tons from 7.1 thsd. ha (Production Volume..., 2019).

Water deficit causes $70 \%$ of crop losses worldwide (Boyer, 1996). Chickpea is one of the most drought-tolerant legumes, but in the global production, drought-induced losses in chickpea yield amount to $30-100 \%$ (Yadav et al., 2006). Lentil losses from drought can reach $54 \%$, and extended drought can lead to a complete loss of the crop. Therefore, drought escape is a preferable drought tolerance strategy for lentil. Early flowering and ripening with a high yield potential are the main components of lentil drought tolerance (Darai et al., 2016). Therefore, screening of lentil genotypes for high germination energy, rapid growth, early flowering and ripening are key parameters in assessing drought tolerance. Pea is not tolerant to arid growing conditions (mesophyte), but it is also grown in relatively arid conditions due to a sufficiently deep root system. In the southern regions without irrigation, pea can give a yield provided a total rainfall of at least $130-140 \mathrm{~mm}$ in May-June (Verbitsky, 1992). The beginning of generative organ development until they bloom is the most crucial phase of pea plant ontogenesis (Brezhneva, 2006).
Several methods are used to assess drought tolerance and water use efficiency. These methods include measuring the water potential, turgor, diffusion pressure deficit, chlorophyll stability index, etc. (Verslues et al., 2006). However, most of these methods are expensive and timeconsuming, which is inefficient when screening a large number of accessions in a test population. Field screening is not always possible, because weather conditions are difficult to control, and rainfall shelters are expensive and extremely inconvenient for evaluating large samples. To determine the response of plants to drought and to gain appropriate information about their drought tolerance, a number of methodological approaches are proposed using a wide range of analytical methods (Osmolovskaya et al., 2017). Germination in osmotic solutions is an effective method for evaluating drought tolerance of plants in the early stages, when they are the most susceptible to water lack. Publications describe a lot of variants of such methods applying different substances and various concentrations, where ascorbic acid (El-Tohamy et al., 2013), sucrose (Volkova et al., 1984; Petrenkova, Kucherenko, 2017), $\mathrm{NaCl}$ (Singh et al., 1990) and polyethylene glycol (PEG$6000)$ are used as osmotics.

Determination of sowing qualities of seeds on water deficit is considered a simple and sensitive parameter, shedding light on resistance of seed germination to stressful conditions. Non-ionic high-molecular polymer, PEG-6000, is the most effective for different crops, since it is an inert substance that does not affect vital processes, and also inhibits the development of pathogenic fungi during germination in laboratory conditions. It was shown that PEG-6000 did not inhibit or affect the mobilization of nutrients (Kalefetoglu Macar et al., 2009), therefore, its effect is only associated with inhibition of water influx into seeds.

The main disadvantage of this technique lies in the absence of a universal set of concentrations to investigate different crops. Therefore, each researcher tests accessions at several concentrations of PEG-6000.

Jatoi (2014) explored the response of ten wheat genotypes to germination at different concentrations of PEG-6000 solutions (19, 21, 23 and 25\%) and chose a differentiating osmotic concentration 
for further studies. Other researchers used PEG6000 and PEG-1500 solutions at concentrations of 5, 10, 15 and $20 \%$ to assess drought tolerance of wheat (Gargaun, Ignatova, 2007; Nawaz et al., 2013). Baloch (2012) suggested using only concentrations of 15 and 25\%, while Guo (2013) presented solutions at concentrations of 5, 15 and $25 \%$.

For legumes, there is no universal technique either. Dharanguttikar (2015) used only two pressure values: -0.4 and -0.6 bar. Kalefetoglu Macar (2009) applied $-0.4,-0.6$ and -0.8 Mpa.

For lentils Morgil (2017) used a differentiating concentration of PEG-6000 of 15\%, Sinha (2018) $18 \%$ and Muscolo (2014) 10, 15, 18 and 21\%. Singh (1990) investigated the drought tolerance of pea in PEG solutions with an osmotic potential of $-0.1,-0.2,-0.3,-0.4$ and $-0.5 \mathrm{Mpa}$. Piwowarczyk (2014) used a solute weight of 50, 100 and $150 \mathrm{~g} / \mathrm{L}$ for vetchling. Feng (2018) used concentrations of 5, 10 and 15\% for alfalfa, and Yin (2015) used 5, 10 and $20 \%$ for mung bean.

Singh (1990) showed the effect of PEG-6000 with an osmotic potential of $-0.1,-0.2,-0.3,-0.4$ and $0.5 \mathrm{Mpa}$ on the root and seedling lengths and noted that the higher an osmotic concentration was, the more suppressed growth processes became, though he did not use higher concentrations completely arresting seed germination. In all experiments, germination in distilled water was taken as a control.

Drought tolerance of plants is based on several traits and a challenge to breeders. Here, it is extremely important to study genetic resources with concurrent determination of drought tolerance of starting material and its subsequent inclusion in the breeding process. Presumably, to determine the drought tolerance of each of the crops, PEG-6000 working solutions will have different concentrations. Based on this, the main objective of our study is the search and selection of the working concentration of PEG- 6000 with the maximum differentiating capacity for chickpeas, peas and lentils. Using this approach will further expand information on the level of drought tolerance of each of the studied crops, including a significant amount of accessions from the core collection and will allow us to differentiate the material by the level of drought tolerance.

\section{MATERIALS AND METHODS}

In order to determine the differentiating capacity of PEG-6000 osmotic solutions at various concentrations, grain legumes (chickpea, lentil and pea from the collection of the National Center for Plant Genetic Resources of Ukraine (NCPGRU)) were germinated. For research four accessions were selected with seed germination of at least $75 \%$. The seeds of researched accessions were grown in scientific crop rotation 1 in the collection nursery of the Laboratory of Genetic Resources of Grain Legumes and Groat Crops of the Plant Production Institute named after VYa Yuriev of NAAS (PPI nd. a. VYa Yuriev NAAS), which is located in the Kharkiv District of the Kharkiv Region in the North-East of the LeftBank Forest-Steppe of Ukraine $\left(49^{\circ} 59^{\prime} 31.4^{\prime \prime} \mathrm{N}\right.$, $36^{\circ} 27^{\prime} 39.6^{\prime \prime} \mathrm{E}$ ) in 2018. Laboratory researches were carried out in January-February 2019. For chickpea (Cicer arietinum L.) there were 2 kabuli accessions (cultivars Dniprovskyi Vysokoroslyi and Rozanna from Ukraine) and 2 desi accessions (local accessions: UD0500022 from Georgia and UD0500263 from Ukraine).

Selection of these accessions was based on our results of the previous determination of the drought tolerance of chickpea accessions using drought tolerance indices. According to this assessment, the cultivar Rozanna is mid-tolerant to drought, and Dniprovskyi Vysokoroslyi is a reference of drought tolerance for kabuli type. UD0500022 is the reference of drought tolerance for the desi type, and UD0500263 (desi) is a large-seeded accession, which is the most susceptible to drought (Vus et al., 2017).

Pea (Pisum sativum L.) cultivars were bred at the Plant Production Institute (Oplot and Kharkovskiy Yantarnyy), collection accessions (Camelot (Czech Republic) and Adagumskiy). Oplot and Camelot are leafless semi-dwarf grain cultivars; Kharkovskiy Yantarnyy is a mid-tall normal-leafed cultivar; Adagumskiy is a vegetable semi-dwarf normal-leafed cultivar.

For lentil (Lens culinaris Medik.) there were 2 large-seeded (macrosperma) accessions: cultivars Krasnohradska 49 and Svitanok from Ukraine; two small-seeded (microsperma) accessions: cultivars Stepnaya 244 and L 135 from Russia. Cultivars Krasnohradska 49 and Stepnaya 244 are 
lentil references of drought tolerance (based on results of multi-year field studies).

The method used for seed germination in sucrose (Kobyzeva et al., 2016) was taken as the basis. Accessions were germinated in PEG-6000 solutions of five concentrations $(5,10,15,20$ and $25 \%$, with distilled water as the control) in a thermostat at $21^{\circ} \mathrm{C}$. Solutions were prepared by dissolving the appropriate amount of PEG-6000 in distilled water (water $t=18^{\circ} \mathrm{C}$ ). Before germination, the seeds were treated with $1 \% \mathrm{KMnO}_{4}$ solution for $10 \mathrm{~min}$. Germination was carried out in germination dishes; folded filter paper filters were used as substrate. Seeds were placed in plastic boxes and PEG-6000 solution was added in a volume of $50 \mathrm{ml}$ for lentils, $80 \mathrm{ml}$ for chickpeas and per each boxes. On the third day, $30 \mathrm{ml}$ of solutions of appropriate concentrations, as well as $30 \mathrm{ml}$ of distilled water in the control, were added to the germination boxes with chickpeas and peas. Germination was carried out in a thermostat at a temperature of $21^{\circ} \mathrm{C}$. The experiment was carried out in four replicas of 25 seeds in each, and the control was repeated twice, with 25 seeds each time. On the fifth day, the laboratory seed germinability was evaluated. The percentage of germinated seeds was calculated by the formula

$$
L G=a / b * 100 \%
$$

where

$L G$ is the laboratory germinability (\%), i.e. percentage of germinated seeds,

$a$ is the number of germinated seeds,

$b$ is the total number of seeds in the experiment.

In mathematical calculations, the seed germinability in the experiment was used in relation to the control in percent.

Since the action of osmotic PEG-6000 can be considered as 'poisoning', where in the control without exposure to a 'toxin' we consider a normal sample, and the maximum concentration will completely inhibit the growth processes in all samples, it was necessary to calculate the semilethal dose $\left(\mathrm{LD}_{50}\right)$, i.e. determine the concentration of osmotic at which the average laboratory germination for 4 varieties of each culture is 50\% or as close to it as possible.
The $\mathrm{LD}_{50}$ was calculated by three ways: using unweighted probit analysis, weighted probit analysis and logistic curve equation (Verhulst's curve); the calculations were conducted according to the methods described by Lakin, 1990.

\section{RESULTS}

We found that 25\% PEG-6000 completely inhibited growth processes in accessions of all the crops under investigation. At osmotic concentrations of 5 to $20 \%$, a significant variability in the number of germinated seeds was noted depending on the crop and PEG-6000 concentration.

It was established that the percentage of germinated lentil seeds in solutions of various concentrations related to the control ranged from 0 to $100 \% .5$ and $10 \%$ PEG-6000 did not suppress the lentil seed germination, as the germinability did not drop below 84\%. 15\% PEG-6000 had a slight differentiating capacity: the germinability of Krasnohradska 49 and Stepnaya 244 decreased to $80 \%$ related to the control and the germinability of Svitanok and L 135 remained at the control level. The maximum differentiation was observed at an osmotic concentration of $20 \%$ : the relative germinability of the accessions varied from 24 to $100 \%$.

Having germinated pea in PEG-6000 solutions of various concentrations, we found that the cultivar Camelot could only germinate in 20 and 15\% PEG-6000 (35 and 83\% related to the control, respectively). At an osmotic concentration of $10 \%$, seedlings were obtained from two cultivars: Kharkovskiy Yantarnyy (68\%) and Camelot (at the control level). In 5\% PEG-6000, the percentages of Adagumskiy and Camelot seedlings did not differ from the corresponding controls; Oplot's germinability was $75 \%$; and the germinability of Kharkovskiy Yantarnyy 96\%.

As for chickpea seeds, 20 and 25\% PEG-6000 solutions had an inhibitory effect on the germinability of all the accessions (Table 1).

In $15 \%$ solution, the germination was only observed in drought-resistant accessions, UD0500022 and Dniprovskyi Vysokoroslyi. 5 and 10\% solutions had the maximum differentiating capacity. The germinability of seeds of different chickpea accessions in 5\% osmotic related to the control ranged from 13 to $100 \%$; in $10 \%$ PEG- 600 , the germinability was within $9-100 \%$. 
Table 1. Relative germinability of grain legume seeds (\% of control) depending on the PEG-6000 concentrations

\begin{tabular}{|c|c|c|c|c|c|c|}
\hline \multirow[b]{2}{*}{ Accessions } & \multicolumn{6}{|c|}{ PEG-6000 concentration, $\%$} \\
\hline & 0 (Control) & 5 & 10 & 15 & 20 & 25 \\
\hline \multicolumn{7}{|c|}{ Lentil } \\
\hline Krasnohradska 49 & 100 & 84 & 84 & 80 & 24 & 0 \\
\hline Svitanok & 100 & 100 & 100 & 100 & 42 & 0 \\
\hline Stepnaya 244 & 100 & 96 & 92 & 80 & 28 & 0 \\
\hline L 135 & 100 & 100 & 100 & 100 & 100 & 0 \\
\hline Mean & 100 & 100 & 100 & 95 & 51 & 0 \\
\hline $\mathrm{SD}$ & & 13.4 & 14.7 & 14.5 & 39.6 & 0 \\
\hline \multicolumn{7}{|c|}{ Pea } \\
\hline Oplot & 100 & 75 & 0 & 0 & 0 & 0 \\
\hline Adagumskiy & 100 & 100 & 0 & 0 & 0 & 0 \\
\hline Kharkovskiy Yantarnyy & 100 & 96 & 68 & 0 & 0 & 0 \\
\hline Camelot & 100 & 100 & 100 & 83 & 35 & 0 \\
\hline Mean & 100 & 94.9 & 42.0 & 20.7 & 8.7 & 0 \\
\hline $\mathrm{SD}$ & & 14.3 & 50.2 & 41.3 & 17.4 & 0 \\
\hline \multicolumn{7}{|c|}{ Chickpea } \\
\hline UD0500263 & 100 & 13 & 9 & 0 & 0 & 0 \\
\hline Rozanna & 100 & 71 & 46 & 0 & 0 & 0 \\
\hline UD0500022 & 100 & 100 & 100 & 52 & 0 & 0 \\
\hline Dniprovskyi Vysokoroslyi & 100 & 100 & 63 & 13 & 0 & 0 \\
\hline Mean & 100 & 74 & 54 & 16 & 0 & 0 \\
\hline $\mathrm{SD}$ & & 44.2 & 37.9 & 24.7 & 0 & 0 \\
\hline
\end{tabular}

Taking into account great variations in the germinability of the accessions under investigation at various concentrations, we selected a concentration of solution for further research on a large collection of genetic resources of each grain legume.

Since the action of osmotic PEG-6000 can be considered as 'poisoning', where in the control without exposure to 'toxin' we deal with an intact accession, and the maximum concentration of $25 \%$ completely inhibits growth processes in all the accessions, we decided to calculate $\mathrm{LD}_{50}$ (or semi-lethal dose), i.e. to determine a concentration of osmotic at which the average laboratory germinability across 4 cultivars of each crop will be around $50 \%$.

In biological statistics, when the force of action of damaging factors on biological objects is explored, a specific statistical method is widely used - probit analysis. It is also used to determine $\mathrm{LD}_{50}$ and $\mathrm{LD}_{95}$. This method was first used by Bliss to evaluate pesticide toxicity for insects
(Bliss, 1934). This method has been successfully used in medicine to determine doses of active substances and injury degree (Wang et al., 2018).

To calculate PEG-6000 concentration that will equal $\mathrm{LD}_{50}$ more accurately, three approaches were used: 1) weighted probit analysis, 2) unweighted probit analysis and 3) construction of a logistic curve (Verhulst's curve). As a result, the equation for calculating PEG-6000 concentration for the specified percentage of non-germinated seeds (50\%) has been derived:

$$
Y=0+1 /\left(1+\mathrm{e}^{\wedge}\left(a^{\star} X+b\right)\right) .
$$

Here:

$Y$ is $(100-L G) / 100$, where $L G$ is the laboratory germinability of seeds,

$X$ is PEG concentration (\%).

Finally, we estimated that the average $\mathrm{LD}_{50}(\%$ of non-geminated seeds) across 4 pea genotypes 
is $50 \%$ and corresponds to the PEG-6000 concentration of $8.359 \%$. At this concentration, the laboratory germinability of the test cultivars will be as follows: Oplot $-4.21 \%$, Adagumskiy $-5.21 \%$, Kharkovskiy Yantarnyy - $92.79 \%$ and Camelot $-97.78 \%$. Such values will account for $99.6 \%$ of the maximum variance. At a PEG-6000 concentration of $8.554 \%$, the average $\mathrm{LD}_{50}$ ( $\%$ of nongerminated seeds) across 4 genotypes is $50.94 \%$, and this is the maximum differentiating concentration for them (Table 2).

Thus, $8.554 \%$ PEG-6000 is the most differentiating concentration to assessing pea genetic resources for drought tolerance in the early stages of vegetation and can be recommended for further screening of collections.

Similarly, the maximally differentiating concentrations of PEG-6000 were calculated at $\mathrm{LD}_{50}$ : the solution concentration for chickpea was $9.675 \%$, and for lentil it was $19.544 \%$. The expected seed germinability of the accessions of each crop at given concentrations was also estimated.

\section{DISCUSSION}

When working with genetic resources, the ability to study a large amount of accessions using a standardized method is important. But as the analysis of literary sources has shown, during the operation of PEG-6000 there are no uniform working concentrations, even for work within the same crop. Studying the resistance of lentils to drought on PEG-6000 solutions, scientists research several concentrations simultaneously on a small number of genoptypes: for example, Dash et al. (2017) studied five accessions at nine concentrations, Manijeh et al. (2018) 49 accessions at three concentrations, and Muscolo (2014) studied four genotypes at four concentrations.

In addition, varieties with large-seeded and small-seeded lentil cultivars differ in drought tolerance (Mishra et al., 2014), therefore, in our research, we studied both subspecies accessions: Krasnogradskaya 49 (macrosperma) and Stepnaya 244 (microsperma) were pre-selected as references of drought tolerance for the corresponding types. In our study, the genotype L 135 (microsperma) significantly exceeded the other accessions in the germination level. While the variety Stepnaya 244 of the same subspecies was significantly inferior to it and demonstrated drought tolerance at the macrosperma-varieties level, which requires further study. According to Mishra et al. (2016), a study of the drought tolerance of lentil genotypes under drought-simulation conditions

Table 2. Predicted germinability of the test accessions at PEG-6000 concentrations with the maximum differentiating capacity

\begin{tabular}{|c|c|c|c|c|c|c|c|c|}
\hline \multicolumn{9}{|c|}{ Crop } \\
\hline \multicolumn{3}{|c|}{ Chickpea } & \multicolumn{3}{|c|}{ Lentil } & \multicolumn{3}{|c|}{ Pea } \\
\hline \multirow[b]{2}{*}{ Accession } & \multicolumn{2}{|c|}{ Germinability, \% } & \multirow[b]{2}{*}{ Accession } & \multicolumn{2}{|c|}{ Germinability, \% } & \multicolumn{3}{|c|}{ Germinability, \% } \\
\hline & 胥 & 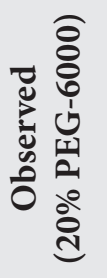 & & 胥 & 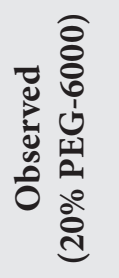 & Accession & 莡 & 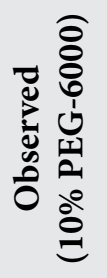 \\
\hline UD0500263 & 0.23 & 8.0 & Krasnohradska 49 & 29.49 & 24.0 & Oplot & 4.21 & 0.0 \\
\hline Rozanna & 38.23 & 44.0 & Svitanok & 40.02 & 32.0 & Adagumskiy & 5.21 & 0.0 \\
\hline UD0500022 & 95.97 & 92.0 & Stepnaya 244 & 31.83 & 28.0 & $\begin{array}{c}\text { Kharkovskiy } \\
\text { Yantarnyy }\end{array}$ & 92.79 & 68.0 \\
\hline $\begin{array}{l}\text { Dniprovskyi } \\
\text { Vysokoroslyi }\end{array}$ & 65.57 & 60.0 & L 135 & 98.66 & 88.0 & Camelot & 97.78 & 92.0 \\
\hline Variance & 87.9 & - & - & 93.0 & - & - & 99.6 & - \\
\hline
\end{tabular}


at the stage of seed formation and filling using mathematical indices and assessment of physiological and biochemical parameters showed that the microsperma subspecies were more resistant to drought than macrosperma, as in physiological and biochemical processes. Simulation of drought using PEG-6000 at the germination fase, as in our work, was carried out by Muscolo (2014), where a significant variability in the amount of germinated lentil seeds on the third day of experiment was also noted. The peak in the variability of the germinability of the studied accessions was observed at osmotic concentrations of 18 and $21 \%$. Calculations of osmotic concentration having the maximum differentiating effect were not carried out. In the researches of Morgil (2017) and Sinha (2018) used concentrations were 15 and $18 \%$, respectively, but percentage germination was determined on the seventh day. Both concentrations had a significant stressful effect on lentil seedlings.

In our work, using the calculating of $\mathrm{LD}_{50}$, we determined a working concentration of osmotic as $19.5 \%$, the use of which will highlight the sources of drought resistance lentil in the core collection of NCPGRU. The effectiveness of using the technique of germination on the PEG-6000 solution for assessing drought tolerance was confirmed studying the expression of genes responsible for biochemical and physiological stress reactions caused by drought (Sinha et al., 2018).

The evaluation of chickpea accessions for drought tolerance by the germination on osmotic solution confirmed the previously obtained data: genotype UD0500263 was the most susceptible to drought (drought susceptibility index (DSI $=1.22$ ) (Vus et al., 2017)). In this study, as low concentration as $5 \%$ decreased its germinability to $13 \%$ related to the control. The cultivar Rozanna, used as a reference in previous studies to evaluate collection accessions in the eastern forest-steppe of Ukraine, had a medium drought susceptibility index and at a concentration of $5 \%$ reduced its germinability by $29 \%$ (down to $71 \%$ related to the control), and at $10 \%$ by $54 \%$.

Accession UD0500022 did not show a significant decrease in the germinability at a concentration of $10 \%$, in contrast to Dniprovskyi Vysokoroslyi (reference of tolerance by the sum of drought tolerance indices) (100 and 63\%, respectively); at an osmotic concentration of $15 \%$, these accessions still preserved their germinability, although it was much lower compared with the control (52 and 13\%, respectively), while seeds of the accession UD0500263 and the cultivar Rozanna did not germinate at all.

Kalefetoglu Macar (2009) analysed the germinability of chickpea seeds in PEG-6000 solutions with an osmotic potential of $-0.4,-0.6$ and $0.8 \mathrm{MPa}$; however, doses that inhibit growth processes were not used.

Al-Saleh et al. (2019) studied five chickpea cultivars at three concentrations of PEG-6000 (0, -3 and -6 bar), but did not notice a significant differentiation in germination: 100, 93.67 and $70.73 \%$, respectively. Koskosidis et al. (2020) studied the effect of different osmotic concentrations ( 0 , $5,10,20,30$ and $50 \%$ PEG) to germination of ten chickpea accessions of a different origin. The authors found that a concentration of $50 \%$ is lethal for seven out of ten cultivars, $30 \%$ for three, $20 \%$ for one. In our study, a concentration of $25 \%$ was lethal for all the studied accessions.

Salma et al. (2016) researched the resistance of seven chickpea cultivars to drought at five concentrations of PEG-6000 (0, 20, 35, 50, 60 g/L) and determined their significant differentiation. The concentration of $35 \mathrm{~g} / \mathrm{l}$ had the maximum differentiation of germination of the studied chickpea genotypes (from 0 to $100 \%$ ). Such differences in the data obtained by different authors can be explained by different genetic content of the studied material, possibly by the edaphic factor and the influence of weather conditions during the growing season.

Our study demonstrated that 9.7\% PEG-6000 could maximally differentiate accessions and be used for evaluation of large chickpea collections. For further studies, we recommend using the accession UD0500022 as a reference of drought tolerance for the desi type and the cultivar Dniprovskyi Vysokoroslyi for the kabuli type.

Pereira et al. (2020) studied the effect of seven osmotic concentrations, including PEG-6000 (0, $-0.2,-0.4,-0.6,-0.8,-1.0$ and $-1.2 \mathrm{MPa})$ on pea seed germination. It was found that seed germination is significantly reduced at a concentration of $-0.6 \mathrm{MPa}$ of PEG-6000. The maximum decrease of germination to $45 \%$ was at a concentration of $-1.2 \mathrm{MPa}$. Okçu et al. (2005) investigated the resistance of three varieties of peas to drought when 
germinated on a PEG-6000 solution with an osmotic potential $(-2,-4,-6$ and -8 bars). A significant decrease in germination (from 11.6 to $80.3 \%$ ) was noted at -6 bars $(-0.6 \mathrm{MPa})$ of PEG. Lethal doses of PEG-6000 were not considered in these works. Petrović et al. (2016) using a PEG-6000 solution of two concentrations $(-0.2,-0.3 \mathrm{MPa})$ in two pea varieties showed a decrease in seed germination of both varieties to $79-83 \%$. A significant differentiation between PEG-6000 solutions of these two concentrations was not observed. In our study, a decrease in germination was observed at various concentrations. So, in two varieties (Oplot, Adagumsky) already at $10 \%$ there were no signs of roots and shoots growth, Kharkovskiy Yantarnyy completely stopped growth processes at $15 \%$, and Camelot at 25\%. Therefore, the cultivar Camelot, which in our study showed the maximum resistance to the stress factor, was preliminary selected as a standard for ranking drought tolerance of pea accessions.

\section{CONCLUSIONS}

The estimated working concentration of solution is $8.6 \%$ for pea, $9.7 \%$ for chickpea and $19.5 \%$ for lentil. Accessions - references of drought tolerance for assessing collections were identified: cultivar Camelot for pea, accession UD0500022 for chickpea and L 135 for lentil. Further studies will verify the method, evaluate collections and identify sources of drought tolerance in grain legumes.

Received 3 March 2020 Accepted 2 October 2020

\section{REFERENCES}

1. Al-Saleh L., Hyass B., Abbas F. 2019. Effect of osmotic potential induced by polyethylene glycol (PEG6000) on the germination of five chickpea (Cicer arietinum L.) varieties. Syrian Journal of Agricultural Research. Vol. 6. No. 3. P. 209-222 [cited 26-05-2020]. Available at: https://agri-researchjournal.net/sjar/wp-content/uploads/2019/09/ v6n3p18.pdf

2. Baloch M., Dunwell J., Khakwani A., Dennett M., Jatoi W., Channa S. 2012. Assessment of wheat cultivars for drought tolerance via osmotic stress imposed at early seedling growth stages. Journal of Agricultural Research. Vol. 50. No. 3. P. 299-310 [cited 20-02-2020]. Available at CentAUR: https:// centaur.reading.ac.uk/29436/
3. Bliss C. 1934. The Method of Probits. Science. No. 79. P. 38-39 [cited 20-02-2020]. Available at Science: https://doi.org/10.1126/science.79.2037.38

4. Boyer J. 1996. Advances in drought tolerance in plants. Advances in Agronomy. No. 56. P. 187-219 [cited 20-02-2020]. Available at ScienceDirect: https://doi.org/10.1016/S0065-2113(08)60182-0

5. Brezhneva V. I. 2006. Pea Breeding in the Kuban. 202 p. (in Russian).

6. Darai R., Ojha B., Sarker A., Sah R. 2016. Genetics and breeding for drought tolerance in food legumes. International Journal of Environment, Agriculture and Biotechnology (IJEAB). Vol. 1. No. 4. P. 958 [cited 20-02-2020]. Available at ResearchGate: https:// dx.doi.org/10.22161/ijeab/1.4.47

7. Dash A., De D., Mohanty S. 2017. Effect of polyethylene glycol induced water stress on seedling development of lentil (Lens culinaris Medik.) genotypes. Environment and Ecology. Vol. 35. No. 1B. P. 558563 [cited 26-05-2020]. Available at: https://www. cabdirect.org/cabdirect/abstract/20173083388.

8. Dharanguttikar V., Bharud R., Borkar V. 2015. Physiological responses of chickpea genotypes for drought tolerance under induced moisture stress. International Journal of Scientific and Research Publications. Vol. 5. No. 9. P. 1-11 [cited 20-022020]. Available at: https://www.ijsrp.org/researchpaper-0915/ijsrp-p4551.pdf

9. El-Tohamy W., El-Abagy H., Badr M., Gruda N. 2013. Drought tolerance and water status of bean plants (Phaseolus vulgaris L.) as affected by citric acid application. Journal of Applied Botany and Food Quality. Vol. 86. No. 1. P. 212-216 [cited 2102-2020]. Available at: https://www.researchgate. net/publication/259233658_Drought_tolerance_ and_water_status_of_bean_plants_Phaseolus_ vulgaris_L_as_affected_by_citric_acid_application

10. FAOSTAT - Food and Agricultural Organization of the United Nations. Statistics [cited 21-02-2020]. Available at: https://www.fao.org/faostat/en/\#data/QC

11. Feng J., Wang D., Shao Ch., Zhang L., Tang X. 2018. Effects of cold plasma treatment on alfalfa seed growth under simulated drought stress. Plasma Science and Technology. No. 20(035505). P. 1-7 [cited 21-02-2020]. Available at: https://pdfs.semanticscholar.org/bbe9/b3089b84c7dd09c05a0f8e27c7dcd05d7d74.pdf

12. Gargaun S. I., Ignatova S. A. 2007. The tolerance of bread wheat explants to osmotic stress in vitro. Visnyk KhNAU. Series. Biolohiia. Vol. 1. No. 10. P. 111-115 [cited 22-02-2020]. Available at: https://vbio.knau.kharkov.ua/uploads/visn_biology/2007/1_10/2007.1.111-115.Gargaun_Ignatova.pdf

13. Grain Legumes. Nourishing Grains of the Future. 2016 [cited 11-04-2018]. Available at: https://www. fao.org/3/a-i5528r.pdf

14. Guo R., Hao W. P., Gong D. Z., Zhong X. L., Gu F. X. 2013. Effects of Water Stress on Germination and 
Growth of Wheat, Photosynthetic Efficiency and Accumulation of Metabolites [cited 21-03-2011]. Available at: https://www.intechopen.com/books/ soil-processes-and-current-trends-in-quality-assessment/effects-of-water-stress-on-germinationand-growth-of-wheat-photosynthetic-efficiencyand-accumulatio

15. Jatoi S. A., Latif M. M., Arif M., Ahson M., Khan A., Siddiqui S. U. 2014. Comparative assessment of wheat landraces against polyethylene glycol simulated drought stress. Science Technology and Development. Vol. 33. No. 1. P. 1-6 [cited 22-022020]. Available at: https://www.researchgate.net/ publication/288567614_Effect_of_PEG_Induced_ Water_Stress_on_Germination_and_Seedling_ Development_of_Tomato_Germplasm

16. Kalefetoglu Macar T., Turan Ö., Ekmekcd Y. 2009. Effects of water deficit induced by PEG and $\mathrm{NaCl}$ on chickpea (Cicer arietinum L.) cultivars and lines at early seedling stages. Gazi Univercity Journal of Science. Vol. 22. No. 1. P. 5-14 [cited 22-02-2020]. Available at: https://pdfs.semanticscholar.org/9647/ 1e40bb9593a96bf4edf87f482e9f17c66810.pdf

17. Kobyzeva L. N., Bezuhla O. M., Sylenko S. I., Kolotylov V. V., Sokol T. V., Dokukina K. I., Vasylenko A. O., Bezuhlyi I. M., Vus N. O. 2016. Methodical Guidelines for Studying Genetic Resources of Grain Legumes (in Ukrainian).

18. Koskosidis A., Khah E., Mavromatis A., Pavli O., Vlachostergios D. 2020. Effect of PEG-induced drought stress on germination of ten chickpea (Cicer arietinum L.) genotypes. Notulae botanicae horti agrobotanici Cluj-Napoca. Vol. 48. No. 1. P. 294-304 [cited 26-05-2020]. Available at: https:// doi.org/10.15835/nbha48111799

19. Lakin G. F. 1990. Biometry. Moscow: Vysshaya Shkola. 352 p. (in Russian).

20. Manijeh S., Farshad S., Ahmad R. 2018. Effect of drought-induced stress by PEG6000 on physiological and morphological traits of lentil (Lens culinaris. Medik.) seed germination in order to selection of drought tolerant genotypes. Iranian Journal of Field Crop Science (Iranian Journal of Agricultural Sciences). Vol. 49. No. 3. P. 39-47 [cited 26-05-2020]. Available at Scientific Information Database: https:// www.sid.ir/en/journal/ViewPaper.aspx?ID=654669

21. Mishra B., Srivastava J., Lal J. 2014. Drought stress resistance in two diverse genotypes of lentil (Lens culinaris Medik.) imposed at different phenophases. Journal of Food Legumes. Vol. 27. P. 307-314 [cited 26-05-2020]. Available at: https://www.researchgate.net/Drought-stress-resistance-in-two -diversegenotypes-of-lentil-imposed-at-different-phenophases.pdf

22. Mishra B., Srivastava J., Lal J., Sheshshayee M. 2016. Physiological and biochemical adaptations in lentil genotypes under drought stress. Russian Journal of Plant Physiology. Vol. 63. P. 695-708 [cited 26-
05-2020]. Available at SpringerLink: https://doi. org/10.1134/S1021443716040117

23. Morgil H., Gercek Y. C., Caliskan M., Cevahir Oz. G. 2017. Investigation of the mechanism of physiological tolerance in lentil (Lens culinaris Medik.) cultivars under drought stress conditions. European Journal of Biology. Vol. 76. No. 1. P. 31-5 [cited 22-02-2020]. Available at: https://www.researchgate.net/publication/322104206_Investigation_of_ the_Mechanism_of_Physiological_Tolerance_in Lentil_Lens_culinaris_Medik_Cultivars_under_ Drought_Stress_Conditions

24. Muscolo A., Sidaria M., Anastasi U., Santonoceto C., Maggio A. 2014. Effect of PEG-induced drought stress on seed germination of four lentil genotypes. Journal of Plant Interactions. Vol. 9. No. 1. P. 354363 [cited 22-02-2020]. Available at: https://www. tandfonline.com/doi/full/10.1080/17429145.2013.8 35880

25. Nawaz S., Ahmed N., Iqbal A., Khaliq I. 2013. Optimization of regeneration protocols for wheat under drought and salt stress. Pakistan Journal of Agricultural Sciences. Vol. 50. No. 4. P. 663-670 [cited 22-02-2020]. Available at: https://pdfs.semanticscholar.org/9249/b4e4ca0bbfbb418b9f2dd04a67f549752732.pdf

26. Okçu G., Kaya M., Atak M. 2005. Effects of salt and drought stresses on germination and seedling growth of pea (Pisum sativum L.). Turkish Journal of Agricultural and Forestry. Vol. 29. P. 237-242 [cited 26-05-2020]. Available at: https://www.researchgate.net/publication/292335983

27. Osmolovskaya N. G., Shumilina J. S., Grishina T. V., Didio A. V., Lukasheva E. M., Bilova T. E., Frolov A. A. 2017. Modeling of drought in the experiment and assessment of its effects on plants. Journal of Stress Physiology \& Biochemistry. Vol. 13. No. 4. P. 110-120 [cited 22-02-2020]. Available at: https://cyberleninka.ru/article/n/modeling-ofdrought-in-the-experiment-and-assessment-of-itseffects-on-plants/viewer

28. Pereira I., Catão H., Caixeta F. 2020. Seed physiological quality and seedling growth of pea under water and salt stress. Revista Brasileira de Engenharia Agrícola e Ambiental. Vol. 24. No. 2. P. 95-100 [cited 26-05-2020]. Available at: https://dx.doi.org/10.1590/1807-1929/agriambi. v24n2p95-100

29. Petrenkova V. P., Kucherenko Ye. Yu. 2017. Assessment of soybean cultivars for drought resistance. Vestnik Kurskoy Gosudarstvennoy Selskokhozyaystvennoy Akademii. No. 2. P. 20-23 [cited 22-022020]. Available at: https://www.journal-kgsha.ru/ data/documents/2017-02.pdf (in Russian).

30. Petrović G., Jovičić D., Nikolić Z., Tamindžić G., Ignjatov M., Milošević D., Milošević 2016. Comparative study of drought and salt stress effects on germination and seedling growth of pea. 
Genetika. Vol. 48. No. 1. P. 373-381 [cited 26-052020]. DOI: 10.2298/GENSR1601373P.

31. Piwowarczyk B., Kamińska I., Rybiński W. 2014. Influence of PEG generated osmotic stress on shoot regeneration and some biochemical parameters in Lathyrus culture. Czech Journal of Genetics and Plant Breeding. Vol. 50. P. 77-83 [cited 22-02-2020]. Available at: https://www. researchgate.net/publication/264252815_ Influence_of_PEG_Generated_Osmotic_Stress_ on_Shoot_Regeneration_and_Some_Biochemical_ Parameters_in_Lathyrus_Culture

32. Production Volume, Yield and Harvested Area of Crops by Their Types by Region. 2019. Available at: https://www.ukrstat.gov.ua/operativ/operativ2019/ sg/ovuzpsg/Arh_ovuzpsg_2019_u.html

33. Salma U., Khatun F., Bhuiyan M., Yasmin S., Khan T. 2016. In vitro screening for drought tolerance of some chickpea varieties in Bangladesh. Progressive Agriculture. Vol.27.No. 2.P. 110-118 [cited 26-05-2020]. Available at: https://doi.org/10.3329/pa.v27i2.29319

34. Semba R. 2016. The rise and fall of protein malnutrition in global health. Annals of Nutrition and Metabolism. Vol. 69. No. 2. P. 79-88 [cited 22-022020]. Available at: https://doi:10.1159/000449175

35. Sichkar V., Orekhovskyi V., Kryvenko A., Mamatov N., Solomonov R. 2018. Peculiarities of biology of lentil development. Visnyk Kharkivskoho Nationalnoho Ahrarnoho Universytetu. Vol. 1. P. 190-203 [cited 22-02-2020]. Available at: https://visnykagro.knau.kharkov.ua/wp-content/ uploads/2020/01/1_2018.pdf (in Ukrainian).

36. Singh M., Singh B. B., Ram P. C. 1990. Effect of iso-osmotic levels of salt and PEG-6000 on germination and early seedling growth of pea (Pisum sativum L.). Biologia plantarum. Vol. 32. No. 3. P. 226-231. Available at: https://bp.ueb.cas.cz/pdfs/ bpl/1990/03/16.pdf, https://bp.ueb.cas.cz/pdfs/ bpl/1990/03/16.pdf

37. Sinha R., Pal A. K., Singh A. K. 2018. Physiological, biochemical and molecular responses of lentil (Lens culinaris Medik.) genotypes under drought stress. Indian Journal of Plant Physiology. Vol. 23. No. 4. P. 772-784 [cited 26-05-2020]. Available at Springer: https://link.springer.com/article/10.1007/ s40502-018-0411-7

38. Verslues P. E., Agarwal M., Katiyar-Agarwal S., Zhu J., Zhu J.-K. 2006. Methods and concepts in quantifying resistance to drought, salt and freezing, abiotic stresses that affect plant water status. The Plant Journal. Vol. 45. P. 523-539 [cited 22-022020]. Available at: https://onlinelibrary.wiley.com/ doi/epdf/10.1111/j.1365-313X.2005.02593.x

39. Volkova A. M., Kozhushko N. N., Makharov B. I. 1984. Determination of the Relative Heat Resistance and Drought Tolerance of Grain Legume Accessions by Germination of Seeds in Sucrose Solutions and After Heating. Methodical Guidelines. 17 p. (in Russian).

40. Vus N. A., Kobyzeva L. N., Bezuglaya O. N. 2017. Breeding value of chickpea accessions in terms of drought resistance in the conditions of the eastern forest-steppe of Ukraine. Naukovi Dopovidi NUBiP = Scientific Reports of the National University of Life and Environmental Sciences. Vol. 4. No. 68 [cited 20-02-2020]. Available at: https://dx.doi. org/10.31548/dopovidi2017.04.008.

41. Wang H., Burgei W. A., Zhou H. 2018. Dose-injury relation as a model for uncertainty propagation from input dose to target dose. American Journal of Operations Research. Vol. 8. P. 360-385 [cited 22-022020]. Available at: https://www.researchgate.net/ publication/327692780_Dose-Injury_Relation_ as_a_Model_for_Uncertainty_Propagation_from Input_Dose_to_Target_Dose

42. Yadav S., Redden R., Chen W., Sharma B. 2006. Chickpea Breeding and Management. CABI: Cambridge. 665 p. [cited 22-02-2020]. Available at: https://www.researchgate.net -In-ChickpeaBreeding-and-Management.pdf

43. Yin Z., Liang J., Hao X., Lu H., Hao J., Yin F. 2015. Physiological response of mung bean to polyethylene glycol drought stress at flowering period. American Journal of Plant Sciences. Vol. 6. P. 785-798 [cited 22-02-2020]. Available at: https://www.researchgate.net/publication/276542535_Physiological_ Response_of_Mung_Bean_to_Polyethylene_ Glycol_Drought_Stress_at_Flowering_Period

44. Zander P., Amjath-Babu T., Preissel S., Reckling M., Bues A., Schläfke N., Kuhlman T., Bachinger J., Uthes S., Stoddard F., Murphy-Bokern D., Watson Ch. 2016. Grain legume decline and potential recovery in European agriculture: a review. Agronomy for Sustainable Development. Vol. 36. No. 2. P. 26 [cited 22-02-2020]. Available at: https:// hal.archives-ouvertes.fr/hal-01532455/document 
Nadiia Vus, Antonina Vasylenko,

Vyacheslav Lutenko, Lyubov Kobyzeva,

Olha Bezuhla, Larisa Shevchenko, Sergey Ponurenko,

Feng Baili, Dmitry Saliy

SKIRTINGŲ POLIETILENO GLIKOLIO

KONCENTRACIJŲ İTAKA ANKŠTINIŲ AUGALŲ

ATSPARUMUI SAUSRAI

Santrauka

Straipsnyje aptariama skirtingų PEG-6000 koncentracijų ita-

ka žirnių, avinžirnių ir lęšių sèklų dygimui.

Vertintas keturių kiekvieno augalo sèklų èminių daigumas 5, 10, 15, 20 ir 25 \% koncentracijų PEG-6000 tirpaluose. Rezultatai parodè, kad 25 \% koncentracijos PEG-6000 tirpalas visiškai nuslopino visų augalų dygimą; 5 ir $10 \%$ koncentracijos PEG-6000 tirpalai neturèjo ịtakos lęšiu sèklų daigumui; didžiausias skirtumas buvo stebètas esant $20 \%$ osmosinei koncentracijai. Avinžirnių daigų nebuvo aptikta net naudojant 20 \% koncentracijos PEG-6000 tirpalą. Kai buvo pasirinktas 15 \% koncentracijos PEG-6000 tirpalas, sausrai atsparių ėminiu 'UD0500022' ir 'Dniprovskyi Vysokoroslyi' veislių sèklos tik sudygo, o 5 ir $10 \%$ koncentracijos tirpalų naudojimas atskleidè didžiausius poveikio skirtumus. Žirnių sèklų daigumo skirtingų koncentracijų PEG-6000 tirpaluose tyrimai parodé, kad tik vieno eminio sèklos sudygo 20 ir $15 \%$ koncentracijos tirpaluose; du èminiai - esant $10 \%$ koncentracijai; $5 \%$ tirpalas beveik neturèjo įtakos žirnių sèklų daigumui.

Raktažodžiai: Cicer arietinum L., daigumas, Lens culinaris Medik, metodas, Pisum sativum L., veislès, sèklos 